\title{
Antenatal Care Practices in Tamang Community of Hilly Area in Central Nepal
}

\author{
Sanjel $\mathrm{S},{ }^{1}$ Ghimire $\mathrm{RH},{ }^{2}$ Pun $\mathrm{K}^{3}$
}

\author{
${ }^{1}$ Department of Community Medicine \\ Kathmandu University School of Medical Sciences \\ Dhulikhel Hospital, Nepal
}

${ }^{2}$ Rural Institution of Community Development (RICOD)

Chapagaun, Lalitpur.

${ }^{3}$ Nursing Program

Kathmandu University School of Medical Sciences

Dhulikhel Hospital, Nepa

Corresponding Author

Seshananda Sanjel

Department of Community Medicine

Kathmandu University School of Medical Sciences

Dhulikhel, Nepal

Email: sanjel.sn@gmail.com

Citation

Sanjel S, Ghimire RH, Pun K. Antenatal care practices in Tamang community of hilly area in central Nepal. Kathmandu Univ Med J 2011;34(2)57-61.

\begin{abstract}
Background

Antenatal care is provided during pregnancy to save lives of mother and foetus. World Health Organization recommends four focused visits as sufficient for normal pregnancy.
\end{abstract}

\section{Objective}

The objective of the study was to find out antenatal care practices in Tamang community of hilly areas of central Nepal.

\section{Methods}

Descriptive cross-sectional study was conducted in Tamang community of Lalitpur district. Systematic random sampling method was used to collect data from April to May 2011. Data of 194 women having $\geq 3$ years of children was collected and analyzed in descriptive and inferential ways.

\section{Results}

Antenatal visits were made by $78.9 \%$ (153) of women but only $46.4 \%$ (71) completed four antenatal visits. Mean visit was of $3.5 \pm 1.13$ times. Ninety four (61.4\%) of first antenatal visits attainders completed the fourth visit. Age of women and antenatal visits, taking tetanus toxoid injection and knowledge on work of iron tablets exhibited significant association at $95 \%$ level of confidence $(p<0.05)$. There was also significant association between numbers of childbirth and antenatal visits at $95 \%$ level of confidence $(p<0.05)$.

\section{Conclusions}

There was a high rate of early marriage and early pregnancy in the Tamang communities. Women did not place high importance on antenatal visits. A large percentage did not complete all four recommended antenatal visits. Use of necessary medicine like iron, albendazole tablets and tetanus toxoid injection was often incomplete.

\section{KEY WORDS}

antenatal visits, central Nepal, hilly areas, Tamang

\section{INTRODUCTION}

Two of the most important indicators of health of a country are life expectancy and maternal mortality rates. ${ }^{1}$ It was supposed that interventions would be needed earlier during the pregnancy to identify women at risk of getting pregnancy related complications, if the mortalities were to be averted. ${ }^{2}$ World Health Organization (WHO) recommends four focused antenatal care (ANC) visits as sufficient for normal pregnancy. ${ }^{3}$ Antenatal Chekcup (ANC) includes education, counseling, screening and treatment to monitor ailments and to promote health of the mother and foetus.

Nepal Demography and Health Survey (NDHS) 2006 recommends that the quality of ANC can be assessed by looking at the type of provider, the number of visits and the timing of the first visit. ${ }^{4}$ ANC visits by pregnant women is $43.7 \%$, institutional delivery is $17.7 \%$, delivery by Skilled Birth Attendance is $18.7 \%$ and postnatal checkups is $33 \%$ in Nepal. ${ }^{5}$ In South East Asian Region, ANC coverage in Sri Lanka is $99 \%$ and $44 \%$ in Nepal, Skilled birth attendance during delivery in Sri Lanka is $99 \%$ and 
$19 \%$ in Nepal and Maternal Mortality Rate (MMR) is lowest in Sri Lanka (23/100,000 live birth) and highest in Nepal (539/100,000 live birth), al of which can be linked. ${ }^{6}$ This study was conducted to find out the status of ANC visits by pregnant woman in the Tamang community.

\section{METHODS}

A Quantitative descriptive cross-sectional study was conducted to find out the ANC practices in the Tamang community of Nallu, Bhardeu and Chaughare Village Development Committees (VDCs) of Lalitpur district, central Nepal. Data was collected using two stage cluster and systematic random sampling methods to select 194 women having $\leq$ 3 years children for interview to fill the questionnaire. Data was collected from April to May 2011 after getting approval from institutional review committee of Kathmandu University School of Medical Sciences (KUSMS) and the District Development Committee of Lalitpur district. The participation for the study was voluntary. All the participants were able to give complete required information for the study. The data was entered in SPSS (statistical package for social science) version 16 for further analysis. Descriptive as well as inferential statistics were measured. Percentage and average were used as descriptive statistics and chi square test was used as inferential statistics.

Table 1. Socio-demographic characteristics.

\begin{tabular}{|c|c|}
\hline Age group & Frequency (\%) \\
\hline $15-19$ years & $18(9.3)$ \\
\hline $20-24$ years & $83(42.8)$ \\
\hline $25-29$ years & $50(25.8)$ \\
\hline $30-34$ years & $24(12.4)$ \\
\hline $35-39$ years & $13(6.7)$ \\
\hline $40-44$ years & $6(3.1)$ \\
\hline Total & $194(100.0)$ \\
\hline \multicolumn{2}{|c|}{ Age at marriage in group } \\
\hline $10-14$ years & $11(5.7)$ \\
\hline $15-19$ years & $124(63.9)$ \\
\hline $20-24$ years & $53(27.3)$ \\
\hline $25-29$ years & $4(2.1)$ \\
\hline $30+$ years & $2(1.0)$ \\
\hline Total & $194(100.0)$ \\
\hline \multicolumn{2}{|c|}{ Age at first pregnancy in groups } \\
\hline $15-19$ years & $87(44.8)$ \\
\hline $20-24$ years & 91 (46.9) \\
\hline $25-29$ years & $14(7.2)$ \\
\hline $30+$ years & $2(1.1)$ \\
\hline Total & $194(100.0)$ \\
\hline \multicolumn{2}{|l|}{ Parity of the women } \\
\hline First parity & 77 (39.7) \\
\hline Second parity & $59(30.4)$ \\
\hline Third parity & $31(16.0)$ \\
\hline Four and more parity & $27(13.9)$ \\
\hline Total & $194(100.0)$ \\
\hline
\end{tabular}

\section{RESULTS}

The quantitative information was obtained from 194 women who have at least a child $\geq 3$ years.

Table 1 shows age of respondents, age at marriage, age at the first pregnancy and parity of the respondents. The mean age of the respondents was 25.62 years (SD, 3.38 years). The mean age at marriage was 18.38 years (SD, 2.90 years). The mean age at first pregnancy was 20.08 years (SD, 2.98 years). The mean child birth was 2.13 (SD 1.297).

Table 2. Antenatal care practices.

\begin{tabular}{|l|l|}
\hline ANC visits & Frequency (\%) \\
\hline Yes & $153(78.9)$ \\
\hline No & $41(21.1)$ \\
\hline Total & $194(100.0)$ \\
\hline $\begin{array}{l}\text { Reasons for non-attendance of ANC (n=41) } \\
\text { (multiple response question) }\end{array}$ & \\
\hline Afraid/ Embarrassed & $23(56.1)$ \\
\hline No problems felt & $12(29.3)$ \\
\hline Think no necessary & $11(26.8)$ \\
\hline No time & $10(24.4)$ \\
\hline No money & $1(2.4)$ \\
\hline Health institution is far way & $1(2.4)$ \\
\hline Number of ANC checkups attended & \\
\hline Once & $11(7.2)$ \\
\hline Twice & $20(13.1)$ \\
\hline Three times & $27(17.6)$ \\
\hline Four times & $71(46.4)$ \\
\hline Five times & $24(15.7)$ \\
\hline Total & $153(100.0)$ \\
\hline Completed months during first visit ANC visit & \\
\hline (n=153) ) (multiple response) & $13(8.5)$ \\
\hline First month & $14(9.2)$ \\
\hline Second month & $68(44.4)$ \\
\hline Third month & $21(13.7)$ \\
\hline Fourth month & $16(10.5)$ \\
\hline Fifth month & $16(10.5)$ \\
\hline Sixth month & $2(1.3)$ \\
\hline Eighth month & $3(2.0)$ \\
\hline Ninth month & $153(100.0)$ \\
\hline Total & (a) \\
\hline Table & \\
\hline
\end{tabular}

Table 2 shows that more than one fourth (78.9\%) of respondents attended ANC visits, which was a bit higher than the national average $(74.0 \%)$. The findings revealed that even though the first ANC visit was usually satisfactory, follow up visits were continually more poorly attended. The number of respondents who attended ANC visits steadily decreased between the first and second, second and third, and third and fourth visits. Even though ANC visits were made, they were not the focused ones. 


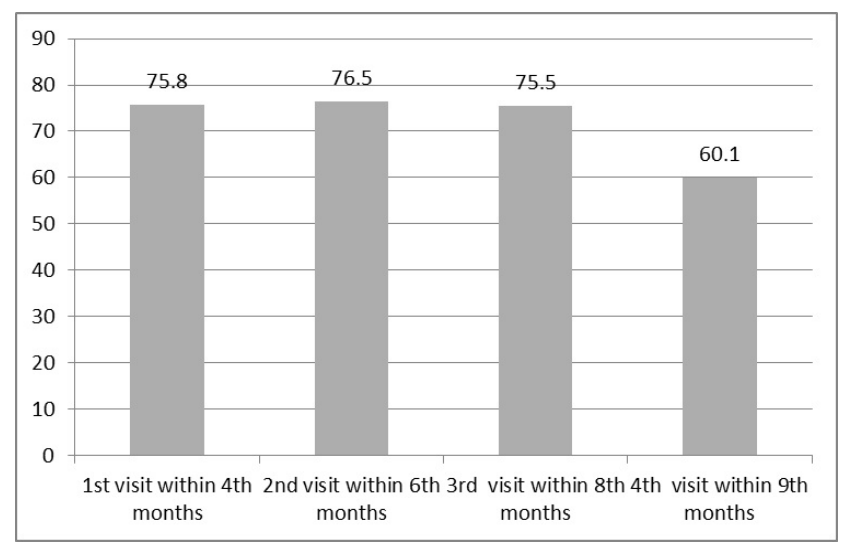

Figure 1. Focused ANC visit within particular months ( $n=153$ )

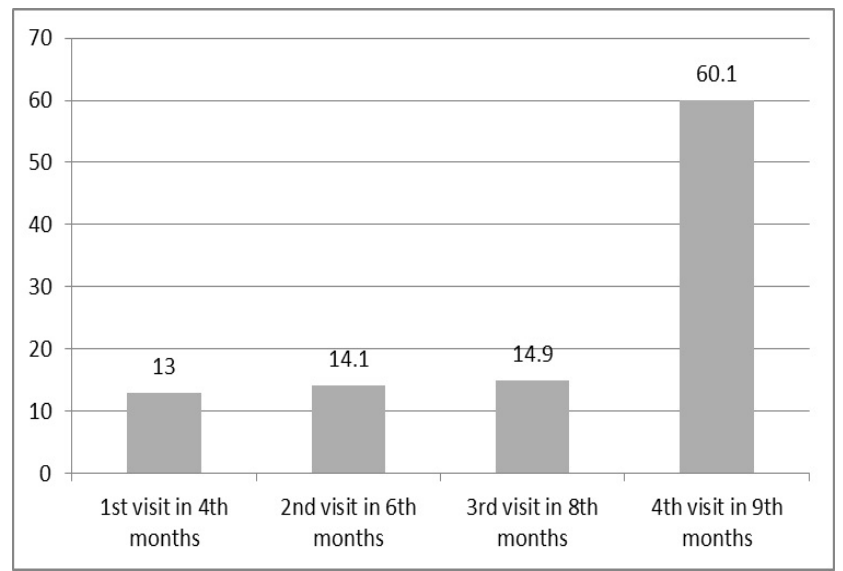

Figure 2. Focused ANC visit in particular month $(n=153)$.

Table 3. Medicine and supplements intake practices.

\begin{tabular}{|ll|}
\hline Medicines (multiple response question) & Frequency (\%) \\
\hline Tetanus Toxid injection & $150(98.0)$ \\
\hline Iron tablets & $145(94.8)$ \\
\hline Albendazole & $96(62.7)$ \\
\hline Reasons for not taking iron tablets $(n=8)$ & \\
\hline Fear of bad effect & $2(25.0)$ \\
\hline Did not like & $2(25.0)$ \\
\hline Did not know the importance & $2(25.0)$ \\
\hline Forgot & $2(25.0)$ \\
\hline Total & $\mathbf{8 ( 1 0 0 . 0 )}$ \\
\hline
\end{tabular}

Table 3 indicates that ninety eight percent of the pregnant women took the tetanus toxoid (TT) injections, about ninety five percent received iron tablets and nearly two thirds received albendazole.

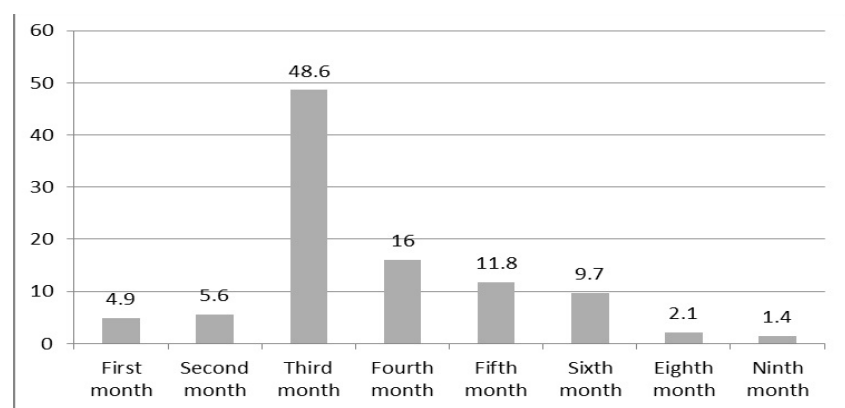

Figure 3. Month when iron tablet consumption was started in percentage $(n=145)$.
Table 4. Comparison of socio-demographic parameters and antenatal services.

\begin{tabular}{|c|c|c|c|}
\hline \multirow{2}{*}{$\begin{array}{l}\text { Age groups in } \\
\text { years }\end{array}$} & \multicolumn{2}{|c|}{ ANC visits during last pregnancy } & \multirow[t]{2}{*}{$P$ value } \\
\hline & Yes & No & \\
\hline $15-19$ years & $17(94.4 \%)$ & $1(5.6 \%)$ & $0.000 * *$ \\
\hline $20-24$ years & $73(88.0 \%)$ & $10(12.0 \%)$ & \\
\hline $25-29$ years & $39(78.0 \%)$ & $11(22.0 \%)$ & \\
\hline 30-34 years & $15(62.5 \%)$ & $9(37.5 \%)$ & \\
\hline $35-39$ years & $4(30.8 \%)$ & $9(69.2 \%)$ & \\
\hline$\geq 40$ years & $5(83.3 \%)$ & $1(16.7 \%)$ & \\
\hline \multirow{2}{*}{$\begin{array}{l}\text { Number of } \\
\text { childbirth }\end{array}$} & \multicolumn{2}{|c|}{ ANC visits during last pregnancy } & $P$ value \\
\hline & Yes & No & \\
\hline One & $69(89.6 \%)$ & $8(10.4 \%)$ & $0.000 * *$ \\
\hline Two & $51(86.4 \%)$ & $8(13.6 \%)$ & \\
\hline Three & $22(71.0 \%)$ & $9(29.0 \%)$ & \\
\hline Four & $10(58.8 \%)$ & $7(41.2 \%)$ & \\
\hline Five & $0(0.0 \%)$ & $5(100.0 \%)$ & \\
\hline Six & $1(50.0 \%)$ & $1(50.0 \%)$ & \\
\hline Seven & $0(0.0 \%)$ & $3(100.0 \%)$ & \\
\hline Total & $153(78.9 \%)$ & $41(21.1 \%)$ & \\
\hline \multirow[t]{2}{*}{$\begin{array}{l}\text { Age groups in } \\
\text { years }\end{array}$} & \multicolumn{2}{|c|}{$\begin{array}{l}\text { Taken iron tablet as instruction } \\
\text { given }\end{array}$} & $P$ value \\
\hline & Yes & No & \\
\hline $15-19$ years & $16(88.9 \%)$ & 2 (11.1\%) & $0.000 * *$ \\
\hline $20-24$ years & 71 (85.5\%) & $12(14.5 \%)$ & \\
\hline $25-29$ years & $36(72.0 \%)$ & 14 (28.0\%) & \\
\hline $30-34$ years & $14(58.3 \%)$ & $10(41.7 \%)$ & \\
\hline $35-39$ years & $2(15.4 \%)$ & $11(84.6 \%)$ & \\
\hline$\geq 40$ years & $5(83.3 \%)$ & $1(16.7 \%)$ & \\
\hline Total & $144(74.2 \%)$ & $50(25.8 \%)$ & \\
\hline \multirow[t]{2}{*}{$\begin{array}{l}\text { Age groups in } \\
\text { years }\end{array}$} & \multicolumn{2}{|c|}{$\begin{array}{l}\text { Taking TT injection during } \\
\text { pregnancy }\end{array}$} & P value \\
\hline & Yes & No & \\
\hline $15-19$ & $14(77.8 \%)$ & $4(22.2 \%)$ & $0.012^{*}$ \\
\hline $20-24$ & $72(86.7 \%)$ & 11 (13.3\%) & \\
\hline $25-29$ & $38(76.0 \%)$ & $12(24.0 \%)$ & \\
\hline $30-34$ & 17 (70.8\%) & 7 (29.2\%) & \\
\hline $35-39$ & $6(46.2 \%)$ & 7 (53.8\%) & \\
\hline$\geq 40$ years & $3(50.0 \%)$ & $3(50.0 \%)$ & \\
\hline Total & 150 (77.3\%) & 44 (22.7\%) & \\
\hline
\end{tabular}

** Significant at $99 \%$ level of confidence

Table 4 shows that there was statistically significant association between age groups and the attendance of ANC services, knowledge on the work of iron tablets and taking iron tablets as instruction given by the health workers at $95 \%$ level of confidence ( $p<0.05$ ). Likewise, numbers of pregnancy and ANC visits during most recent pregnancy demonstrated statistically significant association at $95 \%$ level of confidence $(p<0.05)$. 


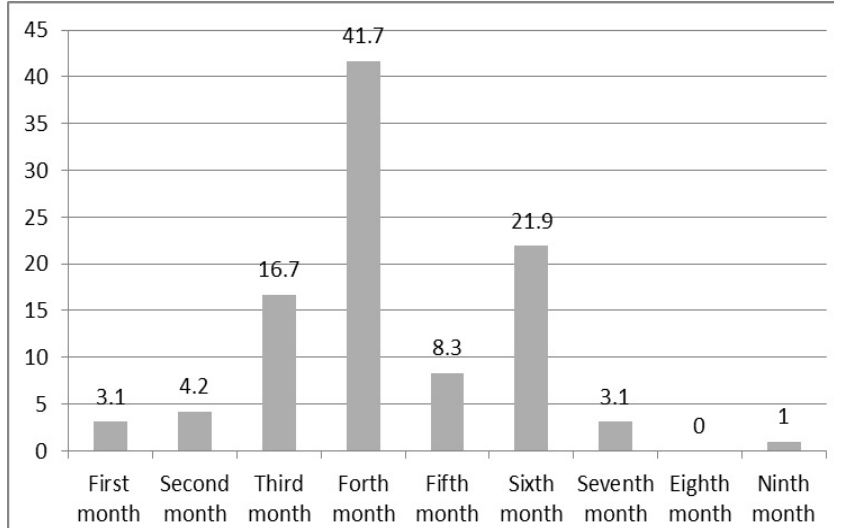

Figure 4. Month when albendazole consumption was started in percentage $(n=145)$.

\section{DISCUSSION}

Poor antenatal care is an important risk factor for adverse pregnancy outcomes among women.2 In current study, the antenatal care (ANC) visits were made by $78.9 \%$ (153) of women which was higher than that of national average (43.7\%).4 It may be due to nearby accessibility of health facilities as stated by Magadi et al that the frequency of antenatal care is also influenced by the accessibility of antenatal care service. 8 Women's health issues in general and women's health care needs in particular are foremost among the public health priorities.9 All pregnancies involve some risks to the mother and/or foetus, and it is important to prevent, detect and manage complications early before they become life-threatening emergencies. ANC visit is an opportunity to get information by women about the danger signs and symptoms for which assistance should be sought from a health care provider without delay.10 Shiffman suggested that antenatal visits enable health personnel to provide information about nutrition, hygiene, and danger signs.11 There is a strong association between the level of antenatal care and delivery care.8,12

In present study majority $(72.7 \%)$ of women replied the purpose of ANC visits were to know the health condition of the mother and fetus. Among 194 participants, 46.4\% (71) completed four ANC visits but the visits were not the focused ones as suggested by standard guidelines. 2,13 Few women went for first visit even within 8th or 9th months of pregnancy. Ideally, the total four ANC visits has to be done at the beginning of 4th, 6th, 8th and 9th months of pregnancy respectively.13 In current study only 94 (61.4\%) of first ANC attendees completed the fourth ANC visit. Even though first ANC visit was satisfactory, gradually follow up visits were lost. Rooney argued that, whether antenatal care can prevent maternal mortality and serious morbidity is a difficult question to answer, but antenatal care is more beneficial in preventing adverse pregnancy outcomes when it is sought early in the pregnancy and is continued through delivery.14

Five percent (8) of women, who attended ANC visits did not take the iron tablet, the reasons behind it were fear of side effect, due to dislike, due to not knowing the importance of iron and due to forgetting to take iron tablets. In our current study, iron tablets were started either as early as first month of pregnancy by few women or late months by a few women which practices are deleterious to the health of mother and foetus. Ninety eight percent of the ANC attendees took tetanus toxoid (TT) vaccine which is higher than the national average (63.0\%).4,12 However, the complications of pregnancies frequently occur among women with no risk factors, hence cannot be predicted, although many may be prevented.11,15 Thus, ANC visits are not to reduce maternal mortality but to reduce the likelihood that a pregnant woman will experience serious complications of pregnancy or childbirth and most importantly, would enable health care providers to identify those women at high risk for complications.15 The use of ANC visits, especially adequate ANC visits is an important factor for safe outcomes. Similarly, Matthews et al revealed that the possibilities of complications that may occur are potentially serious and routine checks are highly desirable during pregnancy.16

Among the respondents, adolescents and women in the oldest age bracket made the best ANC visits that was significant at $95 \%$ level of confidence $(p<0.05)$, which was consistent with the other studies.7,17 The reasons for not attendance of ANC were diverse. Among 41 ANC not attainders it was due to afraid/ embarrassment $56.1 \%$ (23), problems were not felt $29.3 \%$ (12), thought not necessary $26.8 \%(11)$, did not have time $24.4 \%$ (10), and unclear response $4.9 \%$ (2). This result was inconsistent with the findings of Rahman et al that poor attendees were younger than good attendees.19

Obermeyer and Potter illustrated that the age at marriage was not significant predictors of utilization of prenatal care, which is consistent with our present study.20 Incongruent to the above findings it was revealed that, age had a negative relationship with the utilization of ANC and it was found that the young women were more likely to seek antenatal care than older one.3,21 In a pattern study of prenatal care utilization in the United States, Kogan et al found that the young were more likely to begin care later than adults, but similar proportions of young had intensive utilization.22 These finding also indicate that maternal age is one of the important predictors for ANC.

Current study revealed that there was statistically significant association between numbers of childbirth and the ANC visits at $95 \%$ level of significance $(p<0.05)$ as pointed out by other authors that antenatal visit was positively associated with parity.3,7,16,23

Current study revealed that $82 \%$ of respondents experienced no complications during their most recent pregnancy period. Even the problems experienced were minor problems. WHO recommends that a woman without complications have to visit at least four ANC to provide sufficient antenatal care to make possible to detect complications associated with a pregnancy and if any 
complications occur more frequent visits are advised and admission to a health facility may be necessary. 2,24

\section{CONCLUSION}

The study observed that there was a high rate of early marriage and early pregnancy in the Tamang community in the study area. The women of the surveyed communities did not place high importance on antenatal care. In some cases, the women simply did not know the importance of ANC visits, and local health institutions failed to help the respondents to learn about importance of antenatal visits. Among the surveyed women, a large percentage did not complete all four recommended ANC visits. Use of necessary medicine such as iron tablets, albendazole tablets and TT injection was also often incomplete. Lack of knowledge about the reasons for antenatal care practices, health facilities or money led many of the respondents to only partially complete the recommended antenatal visits in local health institution.

\section{REFERENCES}

1. Central Bureau of Statistics. Nepal Census report 2001: Demography. Kathmandu: Central Bureau of Statistics; [Cited 2011, August 27]. WHO. Available from: http://www.cbs.gov.np/national_report_2001. php.

2. Antenatal care in Developing country: An analysis of trends, levels and differentials, 1990-2001. WHO 2003. [cited 2011 Sep 09] Available from: http://www.who.int/entity/making_pregnancy_safer/.../en/ index.html

3. Niroula B. Use of Health Service in Hill Village in Central Nepal. Health Transition Review 1994; 4(2): 151-66.

4. Ministry of Health and Population (MOHP) [Nepal], New ERA, Kathmandu, Nepal and Macro International Inc., Calverton, Maryland, USA. Demographic and Health Survey, Nepal; 2007. pp 135-55

5. Stoltzfus RJ, Dreyfuss ML, Chwaya HM, Albonico M. Hookworm control as a strategy to prevent iron deficiency. Nutr Rev 1997; 55:223-32.

6. Care Concern. A Quarterly Publication to Support Hope Foundation for Women \& Children of Bangladesh; 2004 Inc. Vol. 2, P. 3. [Internet] 1996; [cited 2011 Sep 13]. Available from: http://www. hopeforbangladesh.org/.../newslettervol3may2k5issue1.pdf

7. Blondel B, Marshall B. Poor Antenatal Care in 20 French Districts: Risk Factors and Pregnency Outcomes. Epidemiol Community Health 1998; 52:501-6.

8. Magadi MA, Madise NJ, Rodrigues RN. Frequency and Timing of Antenatal Care in Kenya: Explaining the Variations between Women of different Communities. Social Science and Medicine 2000; 51:55161.

9. Ulincy LD, Simmons SJ. Health care for women: access, utilization, outcome: online book; [Internet] 1993. [cited 2011, Aug 15]. Available from: http://www.mchlibrary.info/.../searchbiblio.php?... Treatment\%20outcome.

10. WHO. Mother Baby Package: Implementing Safe Motherhood in Countries 1996; [Internet] [cited 2011 Sep 16] WHO/FHE/ MSM/94.11. Geneva. Available from: http://www.apps.who.int/gb/ archive/pdf_files/EB107/ee26.pdf

11. Shiffman J. Can Poor Countries Surmount High Maternal Mortality? Studies in Family Planning 2000; 31(4): 274-89.

12. Devkota B. A study of knowledge Attitude and Practices of mother and Maternal and Child Health Care at Pandurung Village 1994. [Unpublished Masters Thesis, Faculty of Eeducation, T.U., Kirtipur].

13. Gopalan C. Low birth weight. In: Nutrition Research in South-East Asia. The Emerging Agenda of the Future. WHO Regional Office for South East Asia, New Delhi, No.23, 1994 pp 13-31. 7 [internet]. [cited 2011, Sep 2]. Available from: http://www.books.google.com.np/ books?isbn=8171795501.

14. Rooney C. Antenatal Care and Maternal Health: How Effective Is It? Maternal Health and Safe Motherhood Program. World Health Organization, Division of Family Health, 1992 [Internet]. [cited 2011 Sep 13]. Available from: http://www.reproline.jhu.edu/...4/nt1744. html.

15. McCarthy J, Maine D. A Framework for Analyzing the Determinants of Maternal Mortality. Studies in Family Planning 1992; 23 (1): 23-33.

16. Matthews Z, Mahendra S, Kilaru A, Ganapathy S. Antenatal care, Care Seeking and Morbidity in Rural Karnataka, India: Result of a prospective study. Asia Pacific Population Journal 2001; 16 (2): 11-28.

17. Elo IT. Utilization of Maternal Health Care Services in Peru: The Role of Women's Education. Health Transition Review, vol. 2, no. 1, pp. 49-69, 1992. [Internet]. [cited 2011 Sep 13]. Available from: http:// www.isrn.com/journals/obgyn/2011/382487/ref/

18. Bhatia JC, Cleland J. Determinants of Maternal Care in a Region of South India. Health transition review1995 [cited 2011, Aug 15]. Available from: http://www.emro.who.int/.../article10.htm.

19. McCaw-Binns A, Grenade JL, Ashley D. Under-Users of Antenatal Care: A Comparison of Non-Attenders and Late Attenders forAntenatal Care, With Early Attenders. Social Science and Medicine 1995; 40 (7):1003-12.

20. Obermeyer CM, Potter JE. Maternal Health Care Utilization in Jordan: A Study of Patterns and Determinants. Studies in Family Planning 1991; 22 (3): 177-87

21. Rahman M, Khudu B, Kane T, Mozumder AK, Reza M. Determinants of Antenatal Care Seeking Behaviors in Bangladesh: Reproductive Health in Rural Bangladesh. ICDDR, B: Center for Health and Population Research 1997; 1:86-104

22. Koenig MA, Fauveaus V, Chowdhury Al, Chakraborty, J. Maternal Mortality in Maltab, Bangladesh. Studies in Family planning 1976-85. Studies in Family Planning; [Internet] 1988. [cited 2011, August 20]. Available from: http://www.who.int/whr/.../index1.html.

23. Celik Y, Hotchkiss DR. The Socioeconomic Determinants of Materna Health Care Utilization in Turkey. Social science and Medicine 2000; 50 (12):1797-1806.

24. WHO. Women's Health in South-East Asia. Women Health Profilefactors Determining Women's Health 2001: WHO Regional Office for South-East Asia [Internet]. [cited 2011 Sep 13]. Available from: http:// www.healthnet.org.np/healthstat/worldbank/women-health.pdf. 